Dikirim: 16 Januari 2017 Diterbitkan: 1 Mei 2017

\section{Ketepatan waktu vaksinasi campak sebagai faktor preventif kejadian campak di kota Yogyakarta}

\section{Timely measles vaccination as a preventive factor on measles occurrence in Yogyakarta}

Anggraeni Budi Lestari ${ }^{1}$, Mei Neni Sitaresmi ${ }^{2}$, Tunjung Wibowo ${ }^{3}$

\begin{abstract}
Purpose: This study aimed to see the relation of timely measles vaccination on measles occurrence. Methods: This research was a matched case control study. A total of 33 cases and 33 controls were used as samples. Case subjects were toddlers aged 9-48 months with measles clinical symptoms (fever, rash and one of cough, cold/runny or conjunctivitis) who were diagnosed by clinic doctors and confirmed by laboratory (positive IgM) and children without measles (healthy) in the same period who came from the neighboring areas in the city of Yogyakarta as controls. Results: Bivariable analysis showed a significant correlation between timely measles vaccination with occurrence of measles disease where $p=0.0042$ and $\mathrm{OR}=7(95 \% \mathrm{Cl}$ : 1.60-63.45). On multivariate analysis, after controlling by including gender and maternal education gained correlation between measles vaccination views of the value of $p=0.008, \mathrm{OR}-8.2(95 \% \mathrm{Cl}: 1.7-40.3)$, gender $\mathrm{OR}=0.95$ $(95 \% \mathrm{Cl}=0.3-2.7)$ and maternal education $\mathrm{OR}=1.96(95 \% \mathrm{Cl}=0.4-9.5)$. Conclusion: There was a correlation between timely measles vaccination with the occurrence of the disease of measles in the city of Yogyakarta.
\end{abstract}

Keywords: timely measles vaccination; disease of measles

\footnotetext{
${ }^{1}$ Departemen Biostatistik, Epidemiologi, dan Kesehatan Populasi, Fakultas Kedokteran, Universitas Gadjah Mada (Email: aini.fkugm@gmail.com)

${ }^{2}$ Departemen Ilmu Kesehatan Anak RSUP Dr. Sardjito

${ }^{3}$ Fakultas Kedokteran, Universitas Gadjah Mada
} 


\section{PENDAHULUAN}

Lebih dari 1,4 juta anak per tahun di dunia meninggal karena berbagai penyakit yang dapat dicegah dengan imunisasi. Penyakit yang dapat dicegah dengan imunisasi adalah batuk rejan 294.000 (20\%), tetanus 198.000 (14\%) dan campak 540.000 (38\%). Kematian karena campak di seluruh dunia terjadi sebesar 122.000 pada tahun 2012, sebanyak 95\% terjadi di negara miskin dan berkembang. Di wilayah Afrika, peningkatan cakupan vaksinasi yang rutin efektif menurunkan kejadian dan kematian karena PD3I (1). Beberapa penyakit menular yang termasuk ke dalam penyakit yang dapat dicegah dengan Imunisasi (PD3I) antara lain difteri, tetanus,hepatitis B, radang selaput otak, radang paru-paru, pertusis, dan polio (2).

Di Indonesia tahun 2013, angka kejadian campak yang dilaporkan sebanyak 11.521 kasus campak, dengan incidence rate (IR) campak sebesar 4,64 per 100.000 penduduk. Provinsi Yogyakarta merupakan wilayah dengan pencapaian kinerja dan derajat kesehatan terbaik di Indonesia. Dimana cakupan imunisasi telah mencapai target diatas dari 95\%, seluruh desa di provinsi Yogyakarta cakupan UCI (universal child immunization) sudah 100\%. Tahun 2012 provinsi yogyakarta melakukan surveilens campak ditemukan sebanyak 379 kasus dimana 356 kasus terjadi di kota Yogyakarta (3). Surveilans berikutnya tahun 2013 di kota Yogyakarta menemukan 32 kasus, tahun 2014173 kasus,tahun 201541 kasus dan pada April 2016 terjadi KLB campak di wilayah Puskesmas Danurejan sebanyak 10 kasus (2).

Penelitian ini difokuskan di kota Yogyakarta karena kasus campak lebih tinggi dari pada kabupaten atau wilayah lain. Cakupan universal child immunization (UCI) sudah 100\%, tetapi cakupan imunisasi di Kota Yogyakarta belum mencapai target UCI sehingga dirasa perlu dilakukan penelitian terkait masalah tersebut. Penelitian ini bertujuan untuk melihat hubungan pemberian waktu vaksinasi campak yang tidak tepat waktu dengan kejadian campak di kota Yogyakarta.

\section{METODE}

Penelitian ini adalah observasional dengan rancangan matched case control. Rancangan matched case control adalah rancangan penelitian epidemiologi yang mempelajari hubungan antara paparan dengan efek tertentu (4). Sampel penelitian ini di dapatkan dari perhitungan besar sampel menggunakan software program sampel size determination in health studies dengan power 90\% diperoleh jumlah sampel 66 anak terdiri dari 33 kelompok kasus dan 33 kelompok kontrol. Kriteria kelompok kasus anak usia 9- 48 bulan dengan gejala klinis campak (demam, rash, batuk, pilek atau conjungtivitis) dikonfirmasi hasil pemeriksaan laboratorium (IgM positif), bertempat tinggal di wilayah kota Yogyakarta dan bersedia menjadi responden. Kelompok kontrol adalah anak yang tidak sakit campak (sehat), tetangga terdekat kelompok kasus dan bersedia menjadi responden. Pemilihan kontrol secara matched tempat tinggal dan umur. Variabel penelitian ini terdiri dari variabel bebas yaitu ketepatan vaksinasi campak variabel terikat yaitu kejadian campak dan variabel luar yaitu jenis kelamin dan pendidikan ibu.

Penelitian ini menggunakan data sekunder yang dikumpulkan melalui buku KIA/kartu imunisasi dan buku kohort bidan di 6 wilayah Puskesmas di kota Yogyakarta. Karena kasus campak tersebar di 6 wilayah puskesmas sebagai berikut; 1) puskesmas Jetis; 2) puskesmas Danurejan II; 3) puskesmas Umbulharjo I; 4) puskesmas Umbulharjo II; 5) puskesmas kota Gede I dan Puskesmas kota Gede II. Alat bantu ukur yang digunakan adalah kuesioner, buku kohort bidan, buku KIA/register imunisasi.

\section{HASIL}

Tabel 1 menunjukkan jenis kelamin terbanyak adalah perempuan yaitu 54,55\%. Pendidikan ibu pada kelompok kasus terbanyak SMA yaitu 42,42\% dan pada kelompok kontrol terbanyak SMA yaitu 57,58\%. Sedangkan berdasarkan ketepatan vaksinasi terbanyak pada kelompok kontrol dan tepat 75,76\%.

Tabel 1. Ciri responden pada kelompok kasus dan kontrol

\begin{tabular}{lcc}
\hline \multicolumn{1}{c}{ Variabel } & Kasus \% (n=33) & Kontrol \% (n=33) \\
\hline Jenis kelamin & & \\
Laki-laki & 45,45 & 51,52 \\
Perempuan & 54,55 & 48,48 \\
Pendidikan ibu & & \\
SD & 0,00 & 3,03 \\
SMP & 21,21 & 18,18 \\
SMA & 42,42 & 57,58 \\
PT & 36,36 & 21,21 \\
Ketepatan vaksinasi & & \\
Tepat & 39,39 & 75,76 \\
Tidak tepat & 60,61 & 24.24 \\
\hline
\end{tabular}

Tabel 2 diketahui bahwa kelompok kasus dan kontrol campak paling banyak di wilayah puskesmas Danurejan (33,33\%). 
Tabel 2. Distribusi Frekuensi kasus campak pada anak per puskesmas di kota Yogyakarta

\begin{tabular}{lcc}
\hline Nama Puskesmas & $\begin{array}{c}\text { Kasus } \\
\text { (\%) }\end{array}$ & $\begin{array}{c}\text { Kontrol } \\
\text { (\%) }\end{array}$ \\
\hline Jetis & 9,09 & 9,09 \\
Umbulharjo 1 & 21,22 & 21,22 \\
Umbulharjo 2 & 9,09 & 9,09 \\
Kota Gede 1 & 18.18 & 18,18 \\
Kota Gede 2 & 9,09 & 9,09 \\
Danurejan & 33,33 & 33,33 \\
Total & 100 & 100 \\
\hline
\end{tabular}

Hasil analisis bivariat dengan uji Mc Nemar menunjukan ketepatan vaksinasi campak mempunyai hubungan yang bermakna dengan kejadian campak dengan melihat nilai $\mathrm{p}=0,0042$ dan $\mathrm{OR}=7$ (95\%CI 1,60-63,45), sedangkan hasil analisis multivariat dengan mengikutsertakan variabel jenis kelamin dan pendidikan ibu menunjukkan nilai $\mathrm{p}=0,008$ dan adanya peningkatan $\mathrm{OR}=8,2$ (95\%CI 1,7-40,3). Hal ini dapat diinterpretasikan apabila anak yang mendapatkan vaksinasi campak tidak tepat waktu beresiko terkena campak sebanyak 8,2 kali dibandingkan dengan anak yang mendapatkan vaksinasi campak tepat waktu.

Hasil analisis bivariat dengan uji Mc Nemar hubungan jenis kelamin dengan kejadian campak di dapatkan nilai $\mathrm{p}=0,81$ dan $\mathrm{OR}=0,8$ (95\%CI 027-2,25) sedangkan analisis multivariat didapatkan nilai $\mathrm{p}=0,94$ adanya peningkatan nilai OR = 1,0 (95\%CI 0,3-2,8). Hal ini diinterpretasikan secara statistik tidak ada hubungan antara jenis kelamin anak dengan kejadian campak.

Tabel 3. Hasil analisis bivariat dan multivariat

\begin{tabular}{|c|c|c|c|c|c|c|c|}
\hline \multirow{2}{*}{ Variabel } & \multicolumn{3}{|c|}{ Kategori } & \multicolumn{2}{|c|}{ Bivariat } & \multicolumn{2}{|c|}{ Multivariat } \\
\hline & & Tidak tepat & Tepat & OR (95\%CI) & P-Value & OR (95\%CI) & P-Value \\
\hline \multicolumn{2}{|c|}{ Ketepatan vaksinasi Tidak tepat } & 6 & 14 & $7(1,6-63,4)$ & $0,0042^{*}$ & $8,2(1,7-40,3)$ & $0,008^{*}$ \\
\hline & Tepat & 2 & 11 & & & & \\
\hline Jenis kelamin & Laki-laki & 7 & 8 & & & & \\
\hline \multirow[t]{2}{*}{ Pendidikan ibu } & Rendah & 2 & 5 & $1(0,2-4,3)$ & 1,0 & $1,9(0,4-9,5)$ & 0,39 \\
\hline & Tinggi & 5 & 21 & & & & \\
\hline
\end{tabular}

Hasil analisis bivariat dengan uji Mc Nemar menunjukan ketepatan vaksinasi campak mempunyai hubungan yang bermakna dengan kejadian campak dengan melihat nilai p 0,0042 dan OR 7 (95\%CI 1,60-63,45), sedangkan hasil analisis multivariat dengan mengikutsertakan variabel jenis kelamin dan pendidikan ibu menunjukkan nilai p 0,008 dan adanya peningkatan OR = 8,2 (95\%CI 1,7-40,3). Hal ini dapat diinterpretasikan apabila anak yang mendapatkan vaksinasi campak tidak tepat waktu beresiko terkena campak sebanyak 8,2 kali dibandingkan dengan anak yang mendapatkan vaksinasi campak tepat waktu.

Hasil analisis bivariat dengan uji Mc Nemar hubungan jenis kelamin dengan kejadian campak di dapatkan nilai $\mathrm{p}=0,81$ dan $\mathrm{OR}=0,8(95 \% \mathrm{CI} 0,27-2,25)$ sedangkan analisis multivariat didapatkan nilai $\mathrm{p}=0.94$ ada peningkatan nilai OR = 1,0 (95\%CI 0,3-2,8). Hal ini diinterpretasikan secara statistik tidak ada hubungan jenis kelamin anak dengan kejadian campak.

Hasil analisis bivariat dengan uji Mc Nemar hubungan pendidikan ibu dengan kejadian campak di dapatkan nilai $\mathrm{p}=1,0, \mathrm{OR}=1$ (95\%CI 0,2-4,3), sedangkan analisis multivariat di dapatkan nilai $\mathrm{p}=$ 0,39 dan adanya peningkatan nilai $\mathrm{OR}=1,96(95 \% \mathrm{CI}$ 0,4-9,5). Hal ini diinterpretasikan secara statistik tidak ada hubungan pendidikan ibu dengan kejadian campak.
Hasil analisis variabel luar dengan variabel terikat

Tabel 4 menunjukkan tidak ada hubungan bermakna antara jenis kelamin terhadap ketepatan vaksinasi campak. Penelitian ini tidak menemukan hubungan pendidikan ibu terhadap ketepatan vaksinasi campak.

Tabel 4. Hasil analisis bivariat dan multivariat

\begin{tabular}{lcccc}
\hline \multirow{2}{*}{$\begin{array}{l}\text { Variabel } \\
\text { penelitian }\end{array}$} & \multicolumn{2}{c}{$\begin{array}{c}\text { Ketepatan } \\
\text { vaksinasi }\end{array}$} & P- & OR (95\%CI) \\
\cline { 2 - 3 } & $\begin{array}{c}\text { Tidak } \\
\text { Tepat } \\
\text { n (\%) }\end{array}$ & $\begin{array}{c}\text { Tepat } \\
\text { n (\%) }\end{array}$ & Value & \\
\hline Jenis kelamin & 16 & 18 & 0,43 & $0,67(0,22-2,01)$ \\
Perempuan & $(57,14)$ & $(47,37)$ & & \\
Laki-laki & 12 & 20 & & \\
Pendidikan ibu & $(42,86)$ & $(52,63)$ & & \\
Rendah & 4 & 10 & 0,23 & $0,46(0.09-1,9)$ \\
Tinggi & $(14,29)$ & $(26,32)$ & & \\
& 24 & 28 & & \\
\hline
\end{tabular}

\section{BAHASAN}

Dalam penelitian ini di dapatkan hasil bahwa secara statistik baik pada analisis bivariat ataupun multivariat tetap signifikan yaitu anak yang tidak tepat waktu mendapatkan vaksinasi campak berisiko terkena campak sebesar 8,2 kali dibandingkan anak yang mendapatkan vaksinasi tepat waktu. Meskipun 
provinsi Yogyakarta cakupan universal child immunization (UCI) sudah tercapai 100\% tetapi di wilayah kota Yogykakarta belum mencapai 100\% (3). Hal ini disebabkan mobilitas penduduk yang tinggi dan masih ada kelompok yang menolak imunisasi, karena itu kasus campak di kota Yogyakarta lebih tinggi daripada kabupaten/wilayah di provinsi Yogyakarta. Selama 2014 dilaporkan terjadi 2 kali kejadian luar biasa (KLB) Campak di wilayah puskesmas Mantrijeron dan Umbulharjo 2. Berdasarkan studi pendahuluan tahun 2015 terjadi KLB campak pada bulan April di wilayah puskemas Danurejan 2 (5).

Penelitin ini sejalan dengan (6) di kabupaten Banyumas bahwa anak yang tidak vaksin tepat waktu berisiko terkena campak sebesar 3,8 kali dibandingkan anak yang mendapatkan vaksin tepat waktu. Penelitian di Merseyside, UK mendukung penelitian ini menyatakan anak-anak di Merseyside UK yang tidak vaksin tepat waktu berisiko terkena campak sebesar 6,3 kali dibandingkan anak yang mendapatkan vaksin tepat waktu (7). Hal ini karena bayi memiliki maternal antibodi campak yang didapat selama dalam kandungan sehingga terlindungi sebelum tiba waktu imunisasi. Ras, genetik, usia, jenis kelamin, status gizi, status reproduksi, penyakit penyerta, radiasi, sinar ultraviolet, dan pemakaian obat-obatan merupakan faktor yang memengaruhi pembentukan titer maternal antibodi campak (8). Maternal antibodi spesifik terhadap antigen virus campak dan akan hilang pada bulan pertama kehidupan, sementara sistem imun neonates sendiri mulai tumbuh dan berkembang. Bayi mulai mempunyai risiko tinggi untuk infeksi ini terjadi pada saat antibodi maternal mulai menurun dan menghilang. Dan imunisasi bayi sangat penting untuk segera dilakukan. Oleh karena itu pemberian vaksinasi campak yang tepat waktu bertujuan untuk mempersempit windows of susceptibility terhadap infeksi campak yaitu jarak antar terjadinya penurunan antibody maternal dari bayi yang diperoleh dari ibu dan antibodi yang muncul sebagai akibat imunisasi(9). Penelitian lain yang bertolak belakang seperti di wilayah kerja puskesmas Weru Sukoharjo oleh menyatakan ketepatan jadwal mengikuti Imunisasi campak tidak memengaruhi kejadian campak (10).

Vaksinasi campak ataupun vaksinasi MMR (Measles,Mumps, Rubella). Sesuai jadwal imuni sasi rekomendasi IDAI tahun 2014, vaksin campak diberikan pada usia 9 bulan. Selanjutnya,vaksin penguat dapat diberikan pada usia 2 tahun. Apabila vaksin MMR diberikan pada usia 15 bulan, tidak perlu vaksinasi campak pada usia 2 tahun. Selanjutnya, MMR ulangan diberikan pada usia 5-6 tahun (11).
Hasil analisis bivariat McNemar menunjukkan hubungan jenis kelamin dengan kejadian campak secara statistik juga tidak bermakna. Hal ini dapat diinterpretasikan jenis kelamin tidak berpengaruh dengan kejadian campak. Pada penelitian ini anak perempuan banyak mengalami campak dibandingkan anak laki-laki. Sejalan dengan penelitian (12) di Eropa dan Amerika menyatakan anak perempuan lebih banyak terkena campak dari pada anak laki-laki meskipun secara statistik tidak bermakna. Meskipun jenis kelamin tidak berpengaruh terhadap kejadian campak tetapi pada KLB (kejadian luar biasa) tahun 2014 di kota Yogyakarta anak laki-laki lebih banyak terkena campak dari pada anak perempuan (5). Penelitian di kota Banjarmasin menyatakan anak dengan jenis kelamin laki-laki, berisiko 1,58 kali untuk terkena campak dibandingkan dengan anak dengan jenis kelamin perempuan (13).

Penelitian ini menemukan hubungan pendidikan ibu dengan kejadian campak secara statistik juga tidak bermakna). Hal ini dapat diinterpretasikan bahwa pendidikan ibu tidak berpengaruh dengan kejadian campak. Padahal sebagian besar responden pada penelitian ini ibunya berpendidikan tinggi tetapi ternyata tidak memberikan pengaruh terhadap ketepatan vaksinasi. Dari jumlah sampel 66 anak sebanyak 28 anak yang vaksinasi nya tidak tepat waktu $85 \%$ berasal dari ibu yang pendidikan tinggi. Sejalan dengan penelitian (14) di wilayah kerja Puskesmas Mangara bombang kabupaten Takalar menyatakan tidak ada hubungan antara pendidikan dengan status imunisasi campak menyatakan tidak dapat dipastikan responden yang berpendidikan tinggi dan rendah mereka akan membawa anaknya ke layanan kesehatan untuk memperoleh vaksinasi karena hal ini berkaitan dengan keyakinan seseorang terhadap manfaat vaksinasi campak. Bertolak belakang dengan penelitian di Kota Banjarmasin menyatakan ibu dengan pendidikan rendah mempunyai risiko 15,76 kali lebih besar, anaknya terkena campak dibandingkan dengan ibu dengan pendidikan tinggi (13).

Pendidikan merupakan salah satu faktor sosial ekonomi yang digunakan sebagai salah satu indikator untuk mengukur tingkat pembangunan SDM dalam suatu daerah. Tingkat pendidikan sebagai salah satu faktor predisposisi terhadap perubahan perilaku. Diharapkan masyarakat yang berpendidikan memiliki kesadaran yang tinggi dalam perilaku hidup sehat sehingga dapat hidup optimal dan sejahtera (15). Dalam Undang Uundang Sistem Pendidikan Nasional Nomor 20 Tahun 2003 menjelaskan bahwa pendidikan adalah proses pembelajaran agar peserta didik secara 
aktif terencana untuk mewujudkan suasana belajar dan proses pembelajaran agar peserta didik secara aktif mengembangkan potensi dirinya untuk memiliki kekuatan spiritual keagamaan, pengendalian diri, kepribadian, kecerdasan, akhlak mulia, dan keterampilan yang diperlukan dirinya, masyarakat, bangsa dan negara. Sedangkan pen- didikan formal adalah jalur pendidikan yang ter- struktur dan berjenjang yang terdiri atas pendidikan dasar, menengah, dan pendidikan tinggi (16).

Secara statistik tidak ada hubungan bermakna antara jenis kelamin terhadap ketepatan vaksinasi campak. Hal ini dapat di interpretasikan bahwa jenis kelamin tidak memengaruhi mendapatkan vaksinasi campak tepat waktu. Tidak ada hubungan pendidikan ibu terhadap ketepatan vaksinasi campak secara statistik tidak bermakna. Penelitian ini sejalan dengan penelitian di wilayah kerja Puskesmas Weru Sukoharjo menyatakan tidak ada hubungan antara tingkat pendidikan dengan ketepatan jadwal mengikuti imunisasi campak. Meskipun pendidikan ibu tinggi tetapi tidak memberikan anak imunisasi tepat waktu karena berbagai alasan sedang pergi ke luar kota, anak sedang mengalami sakit sehingga tidak bisa diberi imunisasi dan ada kelompok yang menolak imunisasi (10).

\section{Faktor lain yang memengaruhi kejadian campak}

Status gizi. Kondisi status gizi kurang memiliki resiko 5.4 kali lebih besar dari pada anak dengan status gizi baik (17). Beberapa penelitian menunjukkan bahwa status gizi kurang berpengaruh terhadap serokonversi titer antibodi sebelum dan sesudah imunisasi campak. Anak dengan gizi buruk akan memetabolisme antibodi maternal untuk mempertahankan ketersediaan protein, sehingga dapat menurunkan antibodi maternal ter- sebut. Peneliti tidak melakukan tahap ini karena data yang diperoleh dilapangan saat penelitian yang diperoleh $\mathrm{BB} / \mathrm{U}$ yang seharusnya $\mathrm{BB} / \mathrm{TB}$ dan tidak lengkap sehingga tidak dapat dilakukan analisis lebih lanjut.

Pemberian vitamin A. Vitamin A berfungsi sebagai imunomodulator yang meningkatkan respon antibodi terhadap virus campak. Pemberian vitamin A dapat menurunkan angka kejadian komplikasi seperti diare dan pneumonia (18). Apabila vitamin A kurang, maka fungsi kekebalan tubuh menjadi menurun, sehingga mudah terserang infeksi. Disamping itu lapisan sel yang menutupi trakea dan paru-paru mengalami keratinisasi, tidak mengeluarkan lender sehingga mudah dimasuki mikroorganisme penyebab infeksi saluran pernapas- an. Bila terjadi pada permukaan usus halus dapat terjadi diare. Perubahan pada permukaan saluran kemih dan kelamin dapat menimbulkan infeksi pada ginjal dan kantong kemih. Pada anak-anak dapat menyebabkan komplikasi pada campak yang dapat mengakibatkan kematian (17). Peneliti tidak meneliti tentang pemberian vitamin A karena data yang diperoleh tidak lengkap.

Cara penyimpanan vaksin (cold chain). Secara umum semua vaksin sebaiknya disimpan disimpan pada suhu $+2 \mathrm{~s} / \mathrm{d}+80 \mathrm{C}$. Vaksin campak yang belum dilarutkan mati dalam 7 hari. Vaksin campak walaupun disimpan pada suhu -25 s/d- 150C, umur vaksin tidak lebih lama dari suhu $+2 \mathrm{~s} / \mathrm{d}+80 \mathrm{C}$ yaitu tetap 2 tahun. Vaksin campak yang belum dilarutkan tidak perlu disimpan di suhu -25 s/d -150C atau freezer. Vaksin campak yang telah dibuka tidak habis harus dibuang setelah 8 jam (19). Untuk mengetahui kedayagunaan vaksin pada konsumen dengan melihat hasil serokonversi (kenaikan titer antibodi) sebelum dan sesudah vaksin namun peneliti tidak melaksanakan tahap ini.

Cara pemberian vaksin. Petugas yang biasa memberikan vaksinasi campak di wilayah kota Yogyakarta adalah bidan atau dokter di Puskemas, Rumah sakit ataupun tempat pelayanan kesehatan lain tergantung balita yang menjadi responden mendapatkan vaksinasi campak. Dosis vaksin terlalu tinggi atau rendah juga memengaruhi respons imun yang terjadi. Dosis terlalu tinggi akan menghambat respons imun yang diharapkan, sedangkan dosis terlalu rendah tidak merangsang sel-sel imunokompeten. Dosis yang tepat dapat diketahui dari hasil uji klinis karena itu dosis vaksin harus sesuai dengan dosis yang di rekomendasikan. Vaksin yang mengandung organisme hidup yang dilemahkan seperti vaksin campak akan menimbulkan respons imun efektif yaitu memberikan perlindungan yang lebih besar dan lama dengan pemberian satu dosis. Rangsangan sel Tc memori membutuhkan sel yang terinfeksi, sehingga diperlukan vaksin hidup untuk menginduksi terbentuknya anti bodi. Pemberian vaksin hidup perlu memperhatikan jadwal waktu pemberian karena bayi masih mem- punyai antibodi maternal yang spesifik (20). Peneliti tidak meneliti tahap ini karena terkait sumber daya manusia (SDM) tenaga pemberi vaksinasi campak di kota Yogyakarta dianggap sudah berkompeten.

\section{SIMPULAN}

Penelitian ini menemukan hubungan antara ketepatan vaksinasi campak dengan kejadian campak. Anak yang tidak mendapatkan vaksinasi tepat waktu 
berisiko terkena campak 7 kali dibandingkan anak yang melakukan vaksinasi tepat waktu. Dinas kesehatan kota Yogyakarta disaranakan perlu peningkatan cakupan imunisasi yang tepat waktu. Untuk bidang kesehatan terutama kesehatan ibu dan anak perlu sosialisasi lebih personal pada kelompok yang menolak program imunisasi.

\section{Abstrak \\ Tujuan: Penelitian ini melihat hubungan pemberian vaksinasi campak yang tidak tepat waktu dengan kejadian campak di kota Yogyakarta. Metode: Jenis penelitian ini adalah matched case control. Sebanyak 33 kasus dan 33 kontrol diambil sebagai sampel penelitian. Kasus adalah anak usia 9-48 bulan dengan gejala klinis campak (demam, rash dan salah satu dari batuk, pilek/beringus atau konjungtivitis) yang didiagnosa oleh dokter puskesmas dan dikon- firmasi hasil pemeriksaan laboratorium. Kontrol adalah anak yang tidak sakit campak (sehat) di periode yang sama berasal dari tetangga kasus. Hasil: Analisis bivariat menunjukkan ada hubungan yang signifikan antara ketepatan vaksinasi campak dengan kejadin campak dimana nilai $\mathrm{p}=0,0042 \mathrm{OR}=$ 7 (95\%CI 1,60-63,45). Analisis multivariat setelah dilakukan pengontrolan dengan memasukan jenis kelamin dan pendidikan ibu diperoleh ketepatan vaksinasi campak signifikan dilihat dari nilai $\mathrm{p}=$ 0,008 OR $=8,2(95 \%$ CI 1,7-40,3), jenis kelamin OR = $0,95(95 \% \mathrm{CI}=0,33-2,7)$ dan pendidikan ibu OR = 1,96 (95\%CI 0,4-9,5). Simpulan: Ada hubungan antara ketepatan vaksinasi campak dengan kejadian campak di kota Yogyakarta.}

Kata kunci: ketepatan vaksinasi, kejadian campak

\section{PUSTAKA}

1. Doshi RH, Mukadi P, Shidi C, Mulumba A, Hoff NA, Gerber S, et al. Field evaluation of measles vaccine effectiveness among children in the Democratic Republic of Congo. Vaccine. 2015;33(29):3407-14.

2. Kementerian Kesehatan. Data dan Informasi Tahun 2013. 2014.

3. Dinas Kesehatan Provinsi Yogyakarta. Profil Kesehatan Daerah Istimewa Yogyakarta Tahun 2013. Yogyakarta; 2013.

4. Dahlan M. Mendiagnosis dan menatlaksana 13 penyakit statistik. Seri. 2010;7:3-12.

5. Dinas Kesehatan Provinsi Yogyakarta. Profil Kesehatan Kota Yogyakarta Tahun 2014. Yogyakarta: Dinkes Kota Yogyakarta; 2015.

6. Sitaresmi MN. Hubungan Status Imunisasi dan Ketepatan Imunisasi Campak dengan Kejadian
Penyakit Campak di Kabupaten Banyumas. Doctoral dissertation, UGM; 2012.

7. Hungerford D, Cleary P, Ghebrehewet S, Keenan A, Vivancos R. Risk factors for transmission of measles during an outbreak: matched case-control study. Journal of Hospital Infection. 2014;86(2):138-43.

8. Raihan R, Andalas M, Satari HI, Hadinegoro SR. Antibodi Campak pada Bayi Baru Lahir dan Faktor yang Memengaruhi. Sari Pediatri. 2016 Oct 14;17(6):407-12.

9. Setiawan I. Penyakit campak. Sagung Seto Cetakan I. 2008:147-9.

10. Destiyanta AP. Hubungan Tingkat Pendidikan, Pekerjaan, dan Pengetahuan Ibu dengan Ketepatan Jadwal Mengikuti Imunisasi Campak di Wilayah Kerja Puskesmas Weru Sukoharjo (Skripsi, UMS); 2015.

11. Ranuh IG, editor. Campak. Pedoman imunisasi di Indonesia. Satgas Imunisasi, Ikatan Dokter Anak Indonesia; 2014.

12. Lin W-HW, Kouyos RD, Adams RJ, Grenfell BT, Griffin DE. Prolonged persistence of measles virus RNA is characteristic of primary infection dynamics. Proceedings of the National Academy of Sciences. 2012;109(37):14989-94.

13. Budi S. Faktor-faktor yang Berpengaruh terhadap Kejadian Campak Pada Peristiwa Kejadian Luar Biasa Campak Anak (0-59 Bulan) di Kota Banjarmasin Provinsi Kalimantan Selatan Tahun 2011: Tesis]. Program Pascasarjana Fakultas Kesehatan Masyarakat Universitas Indonesia, Depok; 2012.

14. Jannah N, Abdullah A, Thaha ILM. Faktor yang berhubungan dengan status imunisasi campak pada Batita di Wilayah kerja Puskesmas Mangarabombang Kabupaten Takalar. 2014.

15. Notoatmodjo S. Promosi Kesehatan dan Perilaku Kesehatan. Jakarta: Rineka Cipta. 2012.

16. Kepres. Undang-Undang Republik Indonesia Nomor 20 Tahun 2003 Tentang Sistem Pendidikan Nasional. 2003.

17. Suardiyasa I, Machfud S. Faktor-faktor risiko kejadian penyakit campak pada anak balita di Kabupaten Tolitoli Propinsi Sulawesi Tengah: Tesis, Universitas Gadjah Mada; 2008.

18. Halim RG. Campak pada Anak. Cermin Dunia Kedokteran. 2016;43(3):186-9.

19. Kementerian Kesehatan. Buku ajar imunisasi. 2014.

20. Kumru OS, Joshi SB, Smith DE, Middaugh CR, Prusik T, Volkin DB. Vaccine instability in the cold chain: mechanisms, analysis and formulation strategies. Biologicals. 2014;42(5):237-59. 